\title{
ОДБРАНА ЈЕДНЕ МЛАДОСТИ АКЦИЈАША: ПРИЛОГ КУЛТУРИ СЕЪАЊА
}

Услед модернизацијских процеса, брзих друштвених промена, иновација и осавремењивања, често се са ниподаштавањем односимо према нашој традицији и прошлости. Из жеље да се раскрсти са прошлошћу долази до одбацивања много чега, без критичког преиспитивања. Није целокупна прошлост, нити све што је старо, за одбацивање, презир и негирање. Морамо се запитати да ли је све у социјалистичком систему, који је у периоду транзиције у капитализам најчешће на удару критика, тако црно како се често представља у данашње време. Једна од тачки спорења су и Омладинске радне акције (OPA). Некима у лепом сећању, као извор многих познанстава, сећање на младалачки полет, дружење, рад на изграђивању ратом разорене државе и сл., а некима извор не тако лепих сећања, напротив. ОРА су у СФРЈ организоване по завршетку Другог светског рата, прва већа савезна омладинска радна акција организована је већ 1946. године: изградња пруге БрчкоБановићи. Ова традиција акцијаштва је потрајала све до 1990. године.

Пред нама је књига Одбрана једна младости акцијаша: прилог култури ceћaњa, у издању Прометеја, библиотеке Пограничје, чији су аутори др Вјекослав Бутиган, др Драгослав Војчић, др Радован Марјановић и др Бранимир Стојковић. Књига се састоји из предговора (Одбрана културе сећања оклеветаних пиротских акиијаша) који је написао В. Бутиган, прве тематске целине (О добровољности учешћа омладине Пирота у омладинским радним акцијама) која садржи текстове поменута четири аутора, као и текст породице Правдољуба Николића (Браниславе, Дејана и Радомира), затим друге тематске целине (Реакције бивших акиијаша и других на оцене о добровољности омладинских радних акиија изнете у тексту у Пиротском зборнику) која се састоји из истраживања које је В. Бутиган спровео и кореспонденције између уредника Пиротског зборника и једног аутора, ${ }^{3}$ и на крају поговора (Одбрана и последюи дани) који је написао приређивач књиге др Драгољуб Ђорђевић.

\footnotetext{
${ }^{1}$ nenad.stanojevic@filfak.ni.ac.rs

${ }^{2}$ Бранимир Стојковић, Вјекослав Бутиган, Драгослав Војчић, Радован Марјановић - Одбрана једне младости акиијаша, Нови Сад: Прометеј, 2020, 183 стр.

${ }^{3}$ Остали аутори критичких текстова нису добили никакав одговор на захтеве да се објаве њихови радови.
} 
На самом почетку би требало указати на повод за писање ове књиге, како бисмо боље разумели тематику, приступ и називе поглавља. Књига је реакција на рад Горана Николића „Радне акције у социјалистичкој Југославији и могућности њиховог поновног организовања" који је објављен у Пиротском зборнику 41/2016. Неки од аутора ове књиге су покушали да објаве своје радове у Пиротском зборнику како би указали на неслагање са поменутим радом, у којем је изнета тврдња да за неке ОРА нису биле добровољне и несебичне, ${ }^{4}$ и да су бројни учесници ОРА из Пирота (посебно сеоски учитељи) направили успешне каријере на основу „позитивних акцијашких карактеристика”. Дакле, књига обухвата радове који су одговор на рад Г. Николића, као и једно истраживање које поткрепљује тврдње аутора.

Насупрот покушају стварања дисконтинуитета са социјалистичком традицијом, поништавања свих тековина социјалистичке модернизације и превредновања чињеница, као што и поднаслов књиге указује (Прилог култури сећањ $a)$, она је покушај неговања и очувања културе сећања која је основа хуманитета и друштвеног прогреса. Одбацују се тврдње да су акције недобровољне и себичне и да су служиле за вертикалну проходност, добијање послова у градовима, заузимање руководећих функција и изградње успешних каријера. В. Бутиган у тексту Одбрана културе сећања оклеветаних акиијаша Пирота истиче да је у раду Г. Николића изнет већи број неистинитих тврдњи (један број њих је произашао услед непоштовања методолошких поступака), пре свега да су млади сеоски учитељи ишли на радне акције ради добијања „позитивних карактеристика" како би издејствовали премештај у град. Указује да њима за остварене каријере нису биле потребне, нити су имали ,акцијашке карактеристике", већ је најпоузданији канал вертикалне друштвене мобилности био рад на образовању и стручном усавршавању, односно знања, способности, напоран интелектуални рад и резултати у раду. Мотиви учешћа у ОРА били су: патриотизам, градитељски занос и жеља да учествују у изградњи земље, као и самопотврђивање у раду, осамостаљење од породице, привикавање на колективни живот, подређивање личног интереса друштвеним, хуманост, солидарност, развијање другарства и пријатељства итд. Д. Војчић у тексту Акиијашке карактеристике и успешне каријере такође излаже неслагање са мишљењем о битној улози позитивне карактеристике у остваривању одређених егзистенцијалних циљева, односно стицању каријере. Сматра да нема доказа да су они са позитивним карактеристикама са радних акција лакше добијали стипендије, упис на факултет, стан и сл. За примере оних који су направили успешне каријере због учешћа на ОРА које наводи Г. Николић, Војчић указује да је дошло до занемаривања осталих битних услова које су они испуњавали, пре свега резултата њиховог рада, радних навика, радне дисциплине, одговорности и упорности. А да само учешће на ОРА није битно утицало на каријеру поје-

\footnotetext{
${ }^{4}$ Ова тврдња се односи на први период организовања ОРА (до 1965. године), док се, када је реч о другом периоду (1965-1989. године), указује на чињеницу да се на акције ишло добровољно и несебично, јер су млади ишли на те акције „ради добре забаве”.
} 
динца потврђују примери оних акцијаша који су били вишеструки ударници на радним акцијама, а нису направили успешне каријере, као и оних који нису учествовали или су напуштали ОРА а касније су направили успешне каријере (управо због резултата у њиховом раду). Р. Марјановић у тексту Мало претенцุиозно и прилично тенденциозно... указује да рад Г. Николића има и добрих страна, али да има и слабе стране, којима је као бивши акцијаш погођен. Као принципијелна слабост објашњавања сложених друштвених појава наводи се монокаузалност. У случају рада који критикује проблем је тврдња да се на акције ишло искључиво ради будуће каријере. ${ }^{5}$ Поставља се питање да ли млади (средњошколци) на том узрасту, одлазећи на акције, заиста имају у виду каријеру? Б. Стојковић у Осврту на „Омладинске радне акицје у соичјалистичкој Југославији и могућност юиховог поновног организовања” Горана Николића каже да је повод за његов осврт то што се у неким деловима рада на основу непотпуне чињеничне основе долази до закључака који су чињенички и логички неутемељени. Пре свега се мисли на места у којима се говори о мотивима за одлазак на радну акцију и о онима која говоре о њима као каналу друштвене мобилности. Сматра да је у поменутом раду на делу логичка грешка post hoc, egro propter hoc, када се на основу тога што нешто претходи нечему изводи закључак да је прво узрок другог (пр. одлазак на радну акцију и успешна професионална каријера), не узимајући у обзир остале чиниоце. Породица преминулог мр Правдољува Николића (Бранислава, Дејан и Радомир) у Реакцији на рад: „,Омладинске радне акиије у социјалистичкој Југославији и могућност юиховог поновног организовања" Горана Николића, објављеном у Пиротском зборнику бp. 41 критикује тврдњу да су се млади сеоски учитељи политички ангажовали у жељи да добију позитивну карактеристику и издејствују премештај у град и констатацију да је велики број акцијаша завршио постдипломске студије (као пример се наводи и мр Правдољуб Николић). Поставља се питање по којој логици је акцијашка прошлост доведена у везу са његовим завршавам постдипломских студија 25 година од учешћа у радним акцијама? Чини се да је и овде уочљива логичка грешка post hoc, egro propter hoc.

У другој тематској целини под називом Реакције бивиих аки̧ијаша и других на оцене о добровољности омладинских радних акиија изнете у тексту у Пиротском зборнику представљено је истраживање В. Бутигана. У истраживању је учествовало 146 испитаника, од којих је 89\% учествовало на ОРА у периоду до 1965. године. Од њих, преко половине су били ученици учитељске школе $(56,8 \%)$, преко четвртине ученици гимназије, економске школе или студенти $(26,7 \%)$, а 5,4 \% њих били су ученици неке друге школе. Преко 10\% испитаника није учествовало на ОРА. Међу испитаницима су били људи различитих образовних квалификација: доктора наука 8,9\%, магистара и специјалиста $3,4 \%$, високообразованих $40,4 \%$, са вишим образовање $28,7 \%$, са средњим

\footnotetext{
5 „Забавно је, у овом контексту, навођење да су сви 'чланови рок групе Бијело дугме учествовали на 'ОРА Козара 76' и то не као музичари неко као бригадири, а тројица су били и ударници'. Нису ваљда због тог учешћа, постали оно за шта важе касније?” (48).
} 
$16,3 \%$, као и $2 \%$ КВ и ВКВ квалификацијом. Испитаницима су путем интервјуа постављена питања о томе да ли знају неке који нису ишли на ОРА добровољно у несебично; због чега су они ишли на ОРА и да ли су због тога остварили неке привилегије; да ли су неки омладинци изли на ОРА због добијања „позитивних карактеристика"; шта мисле о неким тврдњама Г. Николића изнетим у тексту у Пиротском зборнику. Интервјуисани су тврдили да су на ОРА ишли добровољно и несебично, да није било принуде нити тежње за привилегијама. Њихови мотиви су најчешће били: понетост општим омладинским градитељским ентузијазмом, патриотизам, учешће у културно-забавном животу итд. Испитаници се нису слагали са тврдњом да су „позитивне акцијашке карактеристике” помагале да се оствари професионална и политичка каријера. И они испитаници (око 10\%) који нису учествовали на ОРА истичу да им то није доносило никакве неприлике, нити да су били депривилеговани у односу на оне који су учествовали.

Књига Одбрана једне младости акиијаша је значајан прилог култури сећања. У њој се даје увид у позитивна сећања бивших акцијаша на ОРА у првим деценијама после Другог светског рата. Занимљиво је како се у новом и другачијем политичком, економском, друштвеном, вредносном систему гледа на појаву колективног и добровољног рада. Чини се да данас, неколико деценија од престанка организовања акција, оне изгледају као далека прошлост. Међутим, не би требало олако доносити закључке о њима, о мотивима учествовања, последицама (не)учествовања и сл. Сигурно је да књига Одбрана једне младости акцијаша представља добар извор података који не би требало превидети када се о ОРА говори. 